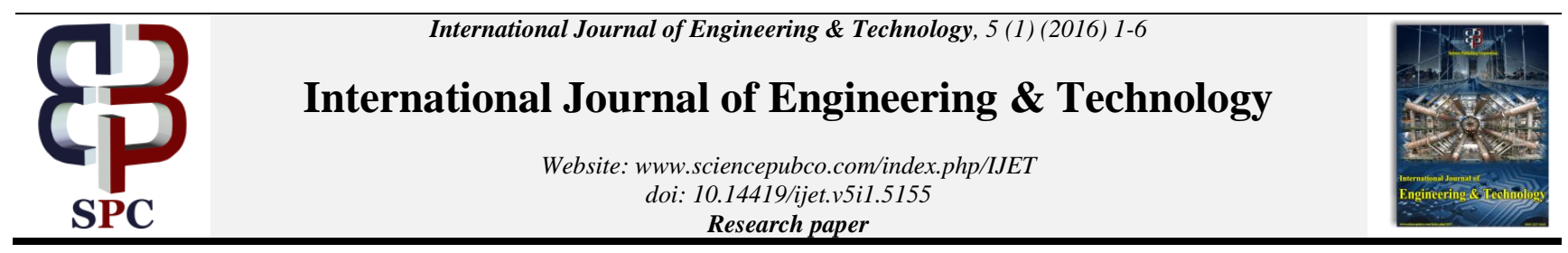

\title{
Development and testing of a motorized cassava fufu pounding machine
}

\author{
Julius Caesar Puoza *, Frimpong Opoku, Bernard Aboagye \\ Department of Mechanical Engineering, Sunyani Polytechnic, Ghana \\ *Corresponding authorE-mail: deokaesar@yahoo.co.uk
}

\begin{abstract}
A motorized cassava fufu pounding machine was developed and tested. The machine principal parts were hopper, throat, pounding compartment, discharge outlet, main frame, electric motor seat, auger, shaft and pulleys. Mild steel material and stainless steel sheet were used in the fabrication based on its availability, strength, appearance, cost, and corrosion resistance. The machine is powered by a 5hp electric motor; the dimension of the machine is $1010 \mathrm{~mm} \times 600 \mathrm{~mm} \times 930 \mathrm{~mm}$ (length $\times$ breadth $\times$ height). Output capacity of $120 \mathrm{~kg} / \mathrm{hr}$ was obtained. The machine is affordable and easy to operate and manage. It is therefore recommended for the restaurants, chop bars and households to prepare a good and hygienic fufu thereby solving the problem of energy sapping and time wasting in manual fufu pounding.
\end{abstract}

Keywords: Development; Motorized; Cassava Fufu; Pounding Machine and Testing.

\section{Introduction}

Fufu, a pounded cooked cassava meal as shown in Fig. 1 [1], is a very popular food in West-Africa (especially Ghana, Cameroon, Nigeria,). It is mainly served with soup and could be eaten at any particular time of the day. It is however, served as lunch or supper in modern times.

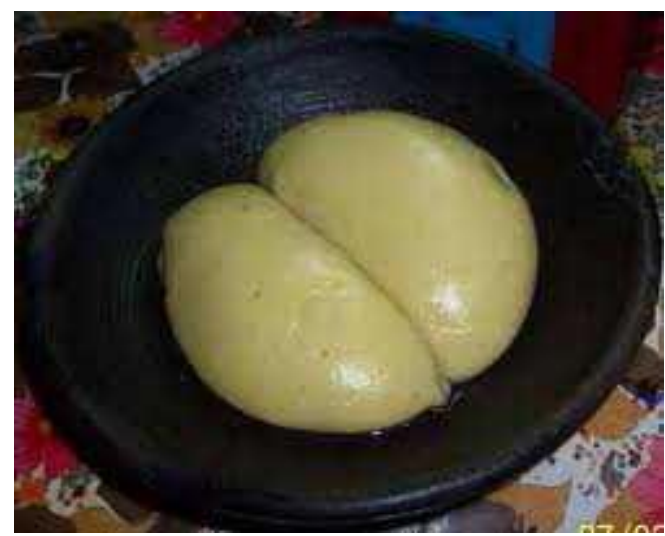

Fig. 1: Fufu.

Fufu is traditionally prepared by pounding boiled, peeled and chopped cassava tubers with a wooden pestle in a wooden mortar until a fine texture is attained (Fig. 2). The cassava is pounded alone or could be mixed with cooked plantain, cocoyam or yam. Fufu is a nutritious meal popular among households of West Africa. Furthermore, the West African community living in diaspora relies on the processed cassava flour ("Neat Fufu" and "Tropical Fufu") [2]. This means that there is a demand for fufu, regionally and internationally. The main disadvantage of fufu is its traditional way of preparation [3]. Pounding fufu is physically energy sap ping and time consuming (Fig. 2) [4]. Potential innovations could be to reduce time and energy while not reducing the quality of the end product. Therefore, the development of a simple fufu pounding machine should be seen as technological breakthrough to satisfy a niche market in the chop bar and restaurant industry. Thus, this work was conceived in the search for a simple technology to process boiled cassava into fufu using locally available materials.

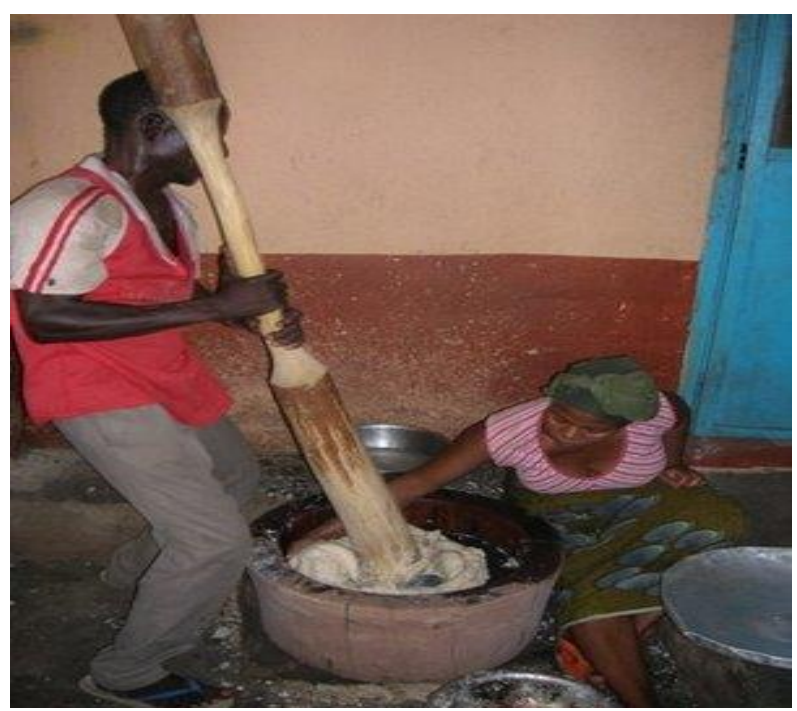

Fig. 2: Traditional Method of Pounding Fufu.

\subsection{Objective of the research}

The objective of this study was to develop a motorized fufu pounding machine which will be efficient, less time consuming with less human effort with a hygienic processing method. 


\section{Description of the machine}

The fufu pounding machine is basically a combination of auger and die. A helical auger is mounted on a shaft, which is supported by bearings so that the shaft rotates in the stationary cylindrical pounding compartment. The orthographic view of the fufu pounding machine is shown in Fig. 3. The fufu pounding machine consists of the following parts: the pounding compartment, a shaft on which is welded the auger, the hopper, the discharge outlet, the bearing and the main frame. Each component was designed following standard engineering principle.

Cassava Pounding Compartment: The pounding compartment as shown in Fig. 3 is made up of an auger in a stainless pipe with cover at both ends. The auger of the pounder was mounted on the driving shaft with a belt pulley as shown in Fig.3. The bigger pulley on the driving shaft transmits power from the electric motor to the pounding compartment through the V-belt.

The Main Frame: The frame of this machine is made up of mildsteel angle iron. The frame holds the pounding compartments and other assemblies such as the bearing, hopper and auger together and at the same time housed the electric motor that generates the required power for operating the cassava fufu pounder.

Auger: A $40 \mathrm{~mm}$ shaft was overlaid with a screw auger of height $90 \mathrm{~mm}$, pitch $60 \mathrm{~mm}$ and over a length of $275 \mathrm{~mm}$. The auger was equipped with $\mathrm{V}$-pulley drive.

Hopper: The hopper was made from a stainless steel sheet of 1.5 $\mathrm{mm}$ thickness. It was designed based on the bulk density of cassava. It was a conical shape hopper. The hopper was welded to the pounding compartment at the slotted opening that admits the boiled cassava and plantain into the pounding compartment.

Fufu die: The fufu die is the heart of the fufu forming operation. In the fufu press, mix cassava and plantain mash is converted to fufu when the mash is pushed through the holes of the die. A die of 110 $\mathrm{mm}$ in diameter and $3 \mathrm{~mm}$ thick was used. The terms that are most important when selecting a fufu die are holes diameter (d); typical holes diameters range from 2.38 to $19.05 \mathrm{~mm}$ [5]. Die with $6 \mathrm{~mm}$ hole diameters were chosen for this design.

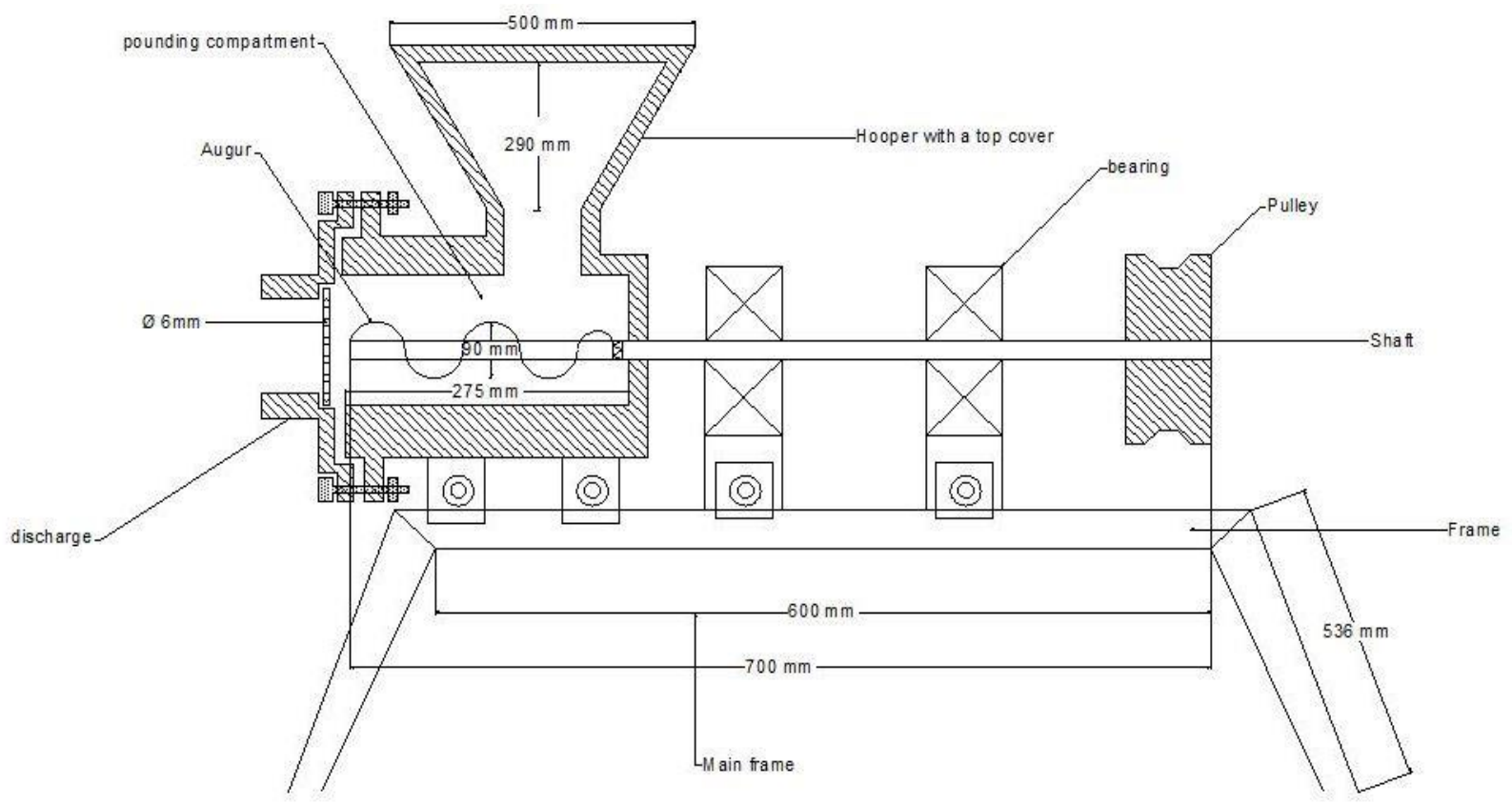

Fig. 3: An Orthographic Drawing of Fufu Pounding Machine

\section{Materials and methods}

In the design and fabrication of the machine, several considerations and assumptions were made. These considerations are in the area of the choice of design, material selection with respect to its properties, load to be overcome by the machine, safety of operation, cost of construction, friction resistance and lubrication, etc. These considerations were carefully done bearing in mind the operation of the machine. Also, the conditions considered in this regard were the tendency of the chosen material to fracture under fatigue, resistance to wear during operation, corrosion when in contact with moisture and ability to radiate heat to the atmosphere to avoid overheating as a result cools the machine while in operation. Material toughness and strength were also considered.

\subsection{Material selection}

Material selection is one of the most important aspects that demand the understanding of each of the functional requirements for the individual machine components. There are ever-increasing varieties of materials presently available and the development of new materials with unique properties and applications [6]. The difficulty in materials selection is a result of these varieties of materials in the engineering field coupled with the complex relationships between the selected parameters and functionality. If the selection process is done haphazardly, the risk of overlooking a possible attractive alternate material may occur. To avoid this there is the need for the analysis of the material performance requirement in the following areas [7]

\subsection{Design factor}

In developing the machine, a number of factors were considered. These include:

i) Strength of the materials for fabrication

ii) Machine capacity

iii) Service requirement

iv) Power requirement

v) Resistance to corrosion attack

vi) Ease of maintenance

vii) Cost

\subsection{Design analysis}

The design analysis was carried out to determine the parameters necessary for the selection of the appropriate grade and size of materials for the fabrication of the various components used.

Design for shaft: A shaft is the rotating machine element which transmits power from one place to another [8]. The shaft of the cassava fufu pounding machine which is rotating the auger and 
pulley will be subjected to twisting moment only. The machine element that exerts force on the shaft is the driven pulley and auger as shown in Fig. 4:

Weight of Pulley,

$\mathrm{W}_{\mathrm{p}}=\mathrm{M}_{\mathrm{p}} \mathrm{g}$

Where,

$\mathrm{M}_{\mathrm{p}}=$ Mass of driven pulley $=1.5 \mathrm{~kg}$

$\mathrm{g}=$ Acceleration due to gravity $=9.81 \mathrm{~m} / \mathrm{s}$

$\mathrm{W}_{\mathrm{p}}=1.5 \times 9.81=14.715 \mathrm{~N}$
Weight of Auger, $\mathrm{W}_{\mathrm{a}}=\rho \mathrm{vg}$

Where,

$\rho=$ Density of material

$=$ For Stainless, $7930 \mathrm{~kg} / \mathrm{m}^{3}$

$=$ For Mild steel, $7860 \mathrm{~kg} / \mathrm{m}^{3}$

$\mathrm{v}=$ Volume of material

Volume of Auger

$=\pi \mathrm{r}^{2} \mathrm{~h}=3.142 \times(0.045)^{2} \times 0.275=1.749 \times 10^{-3} \mathrm{~m}^{3}$

Point Loading of Shaft Due to Auger

$\mathrm{W}_{\mathrm{a}}=7930 \times 1.749 \times 10^{-3} \times 9.81=136.12 \mathrm{~N}$

Auger

Pullev

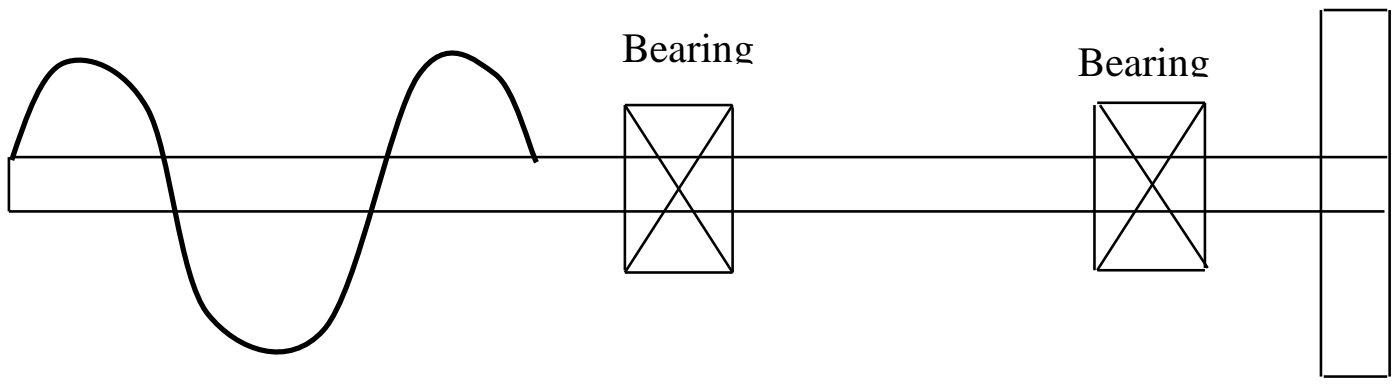

Fig. 4: Shaft Bending Moment Determination.

Reactions at the Bearings Due to Vertical Loading: Below is the expected free body diagram of vertical forces acting on the shaft:

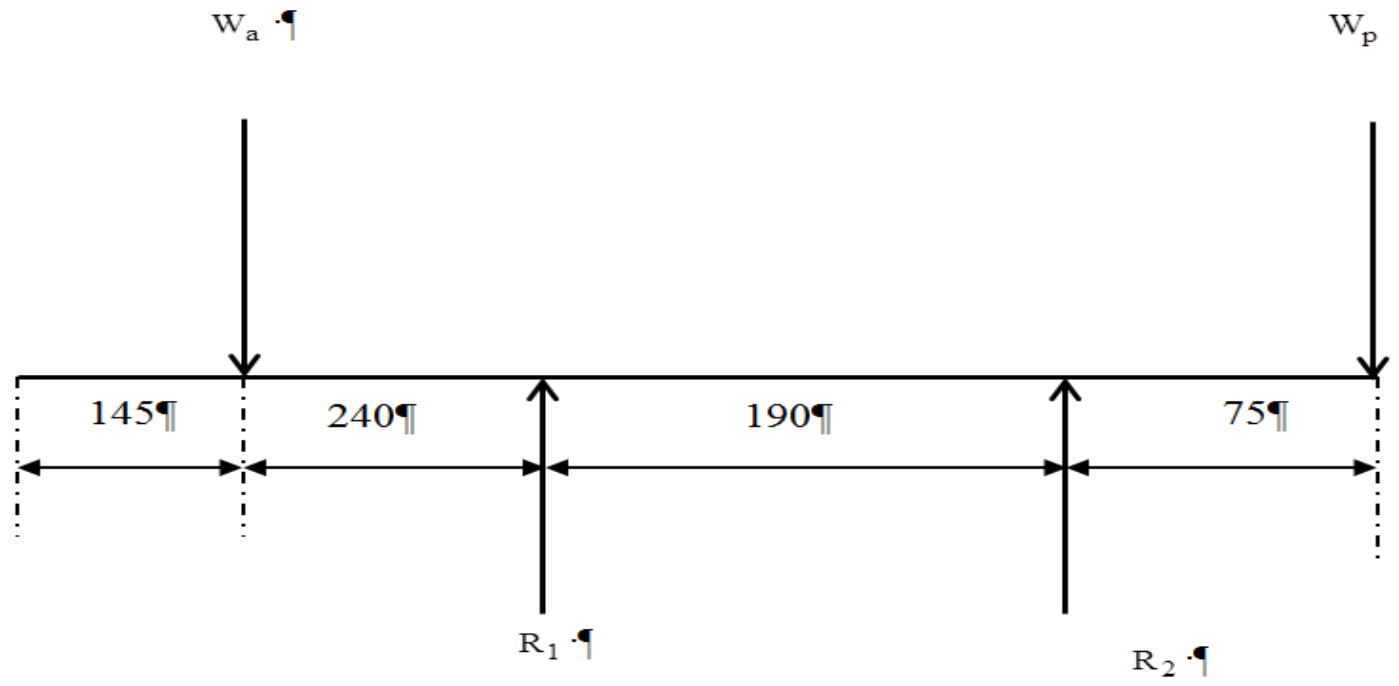

To obtain the reactions at each bearing, we will have to take moment about the two expected bearing points independently.

Taking moment about point $\mathrm{R}_{1}$

$$
\begin{gathered}
\mathrm{W}_{\mathrm{a}} \times 0.24=0.19 \mathrm{R}_{2}+0.265 \mathrm{~W}_{\mathrm{p}} \\
-136.12 \times 0.24=0.19 \mathrm{R}_{2}-14.715 \times 0.265 \\
\mathrm{R}_{2}=-151.4175 \mathrm{~N}
\end{gathered}
$$

Taking moment about point $\mathrm{R}_{2}$

$$
\begin{aligned}
& \mathrm{W}_{\mathrm{a}} \times 0.43+0.19 \mathrm{R}_{1}=0.075 \mathrm{~W}_{\mathrm{p}} \\
& -136.12 \times 0.43+0.19 \mathrm{R}_{2}=-14.715 \times 0.075 \\
& \mathrm{R}_{1}=302.25 \mathrm{~N}
\end{aligned}
$$

The maximum bending moment is obtained from the resultant bending moment

Total bending moment $=$

$(136.12 \times 0.24)+(14.715 \times 0.265)=36.5683 \mathrm{Nm}$

Then, the equivalent twist moment from the torque $=36.5683 \mathrm{Nm}$ For a shaft subjected to twisting moment only, the diameter of the shaft was obtained by using the torsion equation given in Eq. (3):

$$
\mathrm{T}=\frac{\pi}{16} \mathrm{~d}^{3} \tau_{\max }
$$

Where,

$\mathrm{T}=$ Twisting moment $(\mathrm{Nm})$ 
$\tau_{\text {max }}=$ Maximum shear stress $(\mathrm{N} / \mathrm{m} 2)=42 \mathrm{MPa}[6]$

$\mathrm{d}=$ Diameter of shaft $(\mathrm{m})$

$36568.3=\frac{\pi}{16} \times 42 \times \mathrm{d}^{3} \quad \Rightarrow \mathrm{d}=16.43 \mathrm{~mm}$

Selection of the electric motor: An electric motor of the following specification on the name plate was selected based on the design:

Power, $\mathrm{P}=5.5 \mathrm{~kW}(7.5 \mathrm{HP})$

Rotational speed, $\mathrm{N}=1400 \mathrm{RPM}$

Phase $=$ three

Frequency $=50 \mathrm{~Hz}$

Selection of transmission drives: The power transmission drives used for the machine are belt and pulley.

Design for pulley or sheave: The rotor pulley diameter was selected using the equation for the speed ratio shown in Eq. (4):

$$
\mathrm{D}_{\mathrm{r}}=\frac{\mathrm{D}_{\mathrm{m}} \mathrm{N}_{\mathrm{m}}}{\mathrm{N}_{\mathrm{r}}}
$$

Where,

$$
\begin{aligned}
& N_{m}=\text { Rotational speed of electric motor }=1400 \text { RPM } \\
& D_{m}=\text { Diameter of motor's pulley }=130 \mathrm{~mm} \\
& N_{r}=\text { Rotational speed of driven rotor }(\mathrm{RPM})
\end{aligned}
$$

The speed of the rotor was chosen as 1213 RPM.

Design for belt:

Selection of belt type: Based on the power transmitted $(5.5 \mathrm{~kW})$ and according to the Indian standards (IS: 2494-1974), belt type B was selected from the Table 1 .

Table 1: Dimension of Standard V-Belts

\begin{tabular}{lllll}
\hline $\begin{array}{l}\text { Types } \\
\text { of belt }\end{array}$ & $\begin{array}{l}\text { Power } \\
\text { range[kW] }\end{array}$ & $\begin{array}{l}\text { Minimum pitch } \\
\text { diameter of driver } \\
\text { pulley (D) }[\mathrm{mm}]\end{array}$ & $\begin{array}{l}\text { Top } \\
\text { width } \\
\text { (b) }[\mathrm{mm}]\end{array}$ & $\begin{array}{l}\text { Thickness } \\
\text { (t) }[\mathrm{mm}]\end{array}$ \\
\hline A & $0.7-3.5$ & 75 & 13 & 8 \\
B & $2-15$ & 125 & 17 & 11 \\
C & $7.5-75$ & 200 & 22 & 14 \\
D & $20-150$ & 355 & 32 & 19 \\
E & $30-350$ & 500 & 38 & 23 \\
\hline
\end{tabular}

Calculation of belt length, L: Khurmi and Gupta developed equation for calculation of belt length as shown in Eq. (5):

$\mathrm{L}=\frac{\pi}{2}\left(\mathrm{D}_{1}+\mathrm{D}_{2}\right)+2 \mathrm{c}+\frac{\left(\mathrm{D}_{1}+\mathrm{D}_{2}\right)}{4 \mathrm{c}}$

Where,

$\mathrm{L}$ = Length of belt (mm)

$\mathrm{D}_{1}=$ Smaller sheave diameter $=\mathrm{D}_{\mathrm{m}}(130 \mathrm{~mm})$

$\mathrm{D}_{2}=$ Larger sheave diameter $=\mathrm{D}_{\mathrm{r}}(150 \mathrm{~mm})$

$\mathrm{c}=$ Center distance between pulleys $=(440 \mathrm{~mm})$

$\mathrm{L}=\frac{\pi}{2}(130+150)+2 \times 440+\frac{(130+150)}{4 \times 440}=1320.04 \mathrm{~mm}$

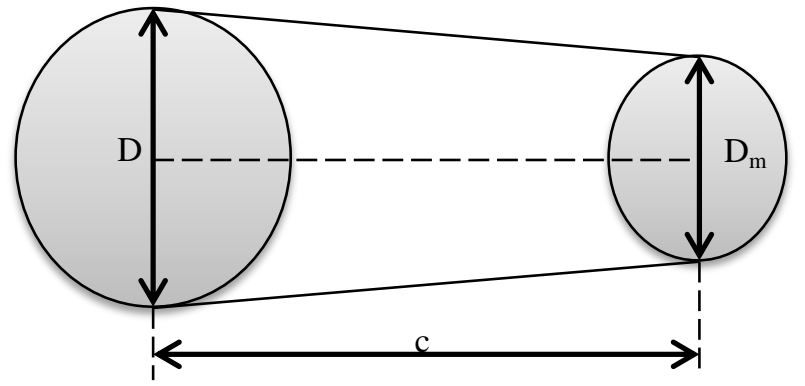

Fig 5: Open Belt Drive.

These parameters are represented in Fig. 5.

Torque: The torque is a function of power and speed of the shaft [9]:

$\mathrm{T}_{\mathrm{q}}=\frac{60 \times \mathrm{P}}{2 \pi \mathrm{N}}$

Where:

$\mathrm{T}_{\mathrm{q}}$ _Torque $(\mathrm{Nm})$

$\mathrm{T}_{\mathrm{q}}=\frac{60 \times 5500}{2 \pi \times 1400}=37.51 \mathrm{Nm}$

Screw Length: Screw length calculation is a function of the equations of a helix, wound on a tapered shaft [9]:

$\mathrm{S}=3.42(\mathrm{r}+\mathrm{ml}) \theta_{2}$

Where

$\mathrm{S}$ - Screw length (m)

$\mathrm{r}$ - Radius of shaft $(\mathrm{m})$

1 - Length of shaft (m)

$\mathrm{m}$ - Tangent of tapping angle (rad)

$\theta_{2}$ - Helix angle (rad)

Volumetric Capacity: The volumetric capacity of a screw is a function of the screw speed, diameter and distance between flights of the screw [9]:

$\mathrm{Q}_{\mathrm{V}}=\pi \mathrm{d}_{\mathrm{S}}^{2} \mathrm{H}_{\mathrm{p}} \mathrm{N}$

Where:

$\mathrm{Q}_{\mathrm{V}}$ - Conveying volume $\left(\mathrm{m}^{3} / \mathrm{s}\right)$

$\mathrm{d}_{\mathrm{s}}$ - Diameter of screw $(\mathrm{m})$

$\mathrm{H}_{\mathrm{p}}$ - Pitch (m)

$\mathrm{N}$ - Screw speed (r/min)

Volumetric Flow Rate: The volumetric flow rate is a function of pressure drop and viscosity [9]:

$Q=K_{d}\left(\frac{\rho_{d}}{\mu_{d}}\right)$

Where:

Q - Volumetric flow rate $\left(\mathrm{m}^{3} / \mathrm{s}\right)$

$\rho_{\mathrm{d}}$ - Total pressure drop $\left(\mathrm{N} / \mathrm{m}^{2}\right)$

$\mu_{\mathrm{d}}$ - Dough viscosity at the die (Pa.s)

$\mathrm{K}_{\mathrm{d}}$ - Die constant (fraction)

Die Constant: Die constant for a die of circular cross-section [9]: 


$$
\mathrm{K}_{\mathrm{d}}=\frac{\tau \mathrm{R}^{4}}{8 \mathrm{~L}_{\mathrm{D}}}
$$

Where:

$\tau$ - Shear stress $\left(\mathrm{N} / \mathrm{m}^{2}\right)$

$\mathrm{R}$ - Nozzle radius (m)

$\mathrm{L}_{\mathrm{D}}$ - Land length of die (m)

Bearing: A 207 pillow bearing was chosen according to ASAE standard [10]. The operating characteristics of a rolling-element bearing depend greatly on its diameter and clearance. The internal diameter of the bearing is $35 \mathrm{~mm}$ while its external diameter is 80 $\mathrm{mm}$.

From the design calculation, the shaft diameter was calculated to be $25.5 \mathrm{~mm}$ (bigger than the $\mathrm{p}$

Bearing diameter). A $40 \mathrm{~mm}$ shaft was obtained from the market and used during fabrication. Part of the shaft was machined to fit the bearings diameter. The screw length and volumetric capacity was calculated to be $0.275 \mathrm{~m}$ and $0.020 \mathrm{~m}^{3} / \mathrm{s}$, respectively. The machine power requirement was calculated as $5.4 \mathrm{~kW}$ of which $5.5 \mathrm{~kW}(7.5 \mathrm{Hp})$ was used for the construction of the machine. The choices of the size of shaft and power requirement was to withstand the resistance of cassava and for stability of the machine.The die plate hole for the plates was drilled using the calculated land length of the die opening of $6 \mathrm{~mm}$.

\subsection{Construction of the machine}

The machineries and machining processes used in the fabrication processes were as follows:

Drilling Machine: This can be hand drilling or pillar drilling machine. This machinery was used for most drilling jobs. The work is stationery while the spindle carrying the drill chuck and bit moves the work must be held with a vice during drilling.

Milling Machine: This machine was used for the cutting of the keyway on the pounder shaft.
Lathe: This was used for an extensive array of precision works such as boring, turning and facing of the assembly parts.

Hand GrindinglCutting Disc Machine: This is hand held and it comes in two sizes. The disc comes in the sizes 9", 7", or 4" diameters. The 7" disc was used for cutting and grinding.

Welding Machine: It is used in conjunction with electrode and tong for joining two or more metals together. It was used with both stainless and mild steel electrode when welding stainless or mild steel. Welding can either be tacking (which can be easily broken) during setting, stitching, (which can be used to hold thin metals $(1 \mathrm{~mm}$ metal sheets together firmly) or running (which is used for thick metal plates, $3 \mathrm{~mm}$ ). The stainless and mild steel electrode of gauge 10 ( $2.5 \mathrm{~mm}$ diameter) was used. Welding glasses (dark) was used when working.

Bending Machine: It is used for bending sheet metals up to $5 \mathrm{~mm}$ thick at different desired angles. It was used for bending the stainless and mild steel plates.

Table Shear: It is big and heavy. It was used for cutting plate less than the $3 \mathrm{~mm}$ and $4 \mathrm{~mm}$ sheet, and it gives a straight cut edge unlike the hand cutting disc.

Pedestal Grinding Machine: It was used for sharpening the tools, work piece drill bits.

\section{Principle of operation of the machine}

Boil cassava tubers are poured into the hopper which passes through the throat into the auger through the inlet gate of the pounding chamber. The auger breaks the boil lumps into mash and conveys it to the die and builds up pressure for extrusion. Pressure resulting from rotating auger forces the mash through the perforations in the die, compressing and forming it into pellets. The pellets were allowed to break off by force of gravity. The collection of the pallet is then done at the discharge outlet as shown in Fig. 6.

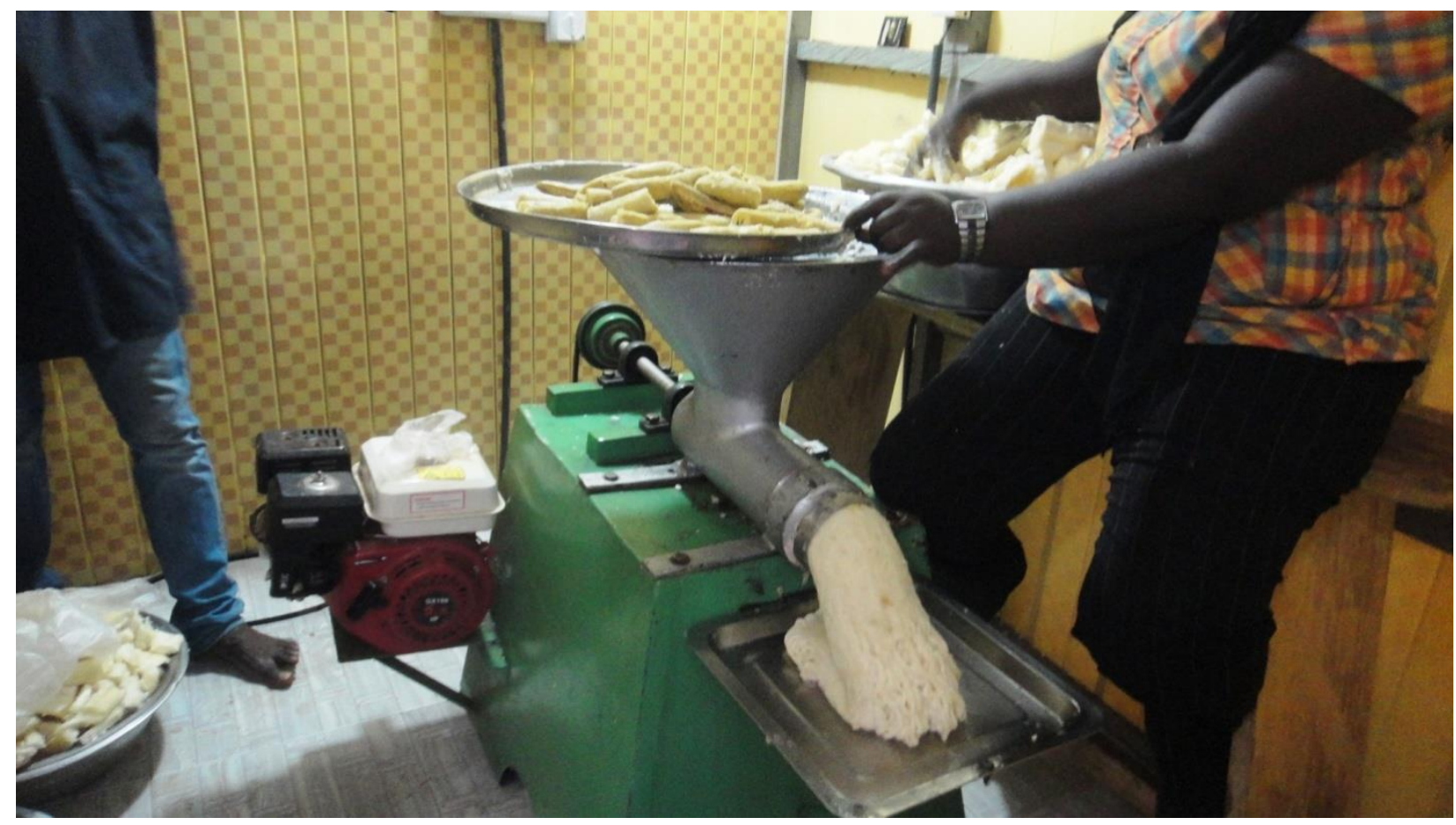

Fig. 6: Fufu Pounding Machine. 


\section{Bill of engineering materials and compo- nents evaluation}

The bill of engineering materials, components and labour evaluation of the machine is shown in table 2 below:

Table 2: Bill of Materials and Components

\begin{tabular}{llllll}
\hline S/N & $\begin{array}{l}\text { Material Com- } \\
\text { ponents }\end{array}$ & Description & Quantity & $\begin{array}{l}\text { Unit } \\
\text { Price } \\
{[\mathrm{GHS}]}\end{array}$ & $\begin{array}{l}\text { Total } \\
{[\mathrm{GHS}]}\end{array}$ \\
\hline 1 & $\begin{array}{l}\text { S/S Metal Rod } \\
\text { for Shaft } \\
2 / S\end{array}$ & $\phi 30 \mathrm{~mm}$ & 1 & 70 & 70 \\
2 & $\begin{array}{l}\text { M/S Angle Bar } \\
\text { for Frame }\end{array}$ & $50 \times 50 \times 3$ & 0.5 & 35 & 35 \\
3 & $\begin{array}{l}\text { Stainless Steel } \\
\text { Sheet }\end{array}$ & $1.5 \mathrm{~mm}$ & 0.5 & 150 & 150 \\
4 & Mild Steel Sheet & $2 \mathrm{~mm}$ & 0.5 & 80 & 80 \\
5 & S/S Pipe & & 1 & 100 & 100 \\
6 & Electric Motor & $5 \mathrm{hp}$ & 16 & 1 & 350 \\
7 & Bolts and Nuts & M12 & 16 & 16 \\
8 & Pillow Block & 205 & 1 pair & 40 & 40 \\
& Bearing & V-belt A- & 1 & 7 & 7 \\
9 & Belt & 52 & 30 & 1 & 30 \\
10 & Electrode & & 60 & 5 & 120 \\
11 & Miscellaneous & hours & 600 \\
12 & Labour Cost & & & & 1,290 \\
\hline & Total & & &
\end{tabular}

\section{Main results}

\subsection{Performance evaluation}

There are several methods of testing for the efficiency of machines, but with respect to this cassava fufu pounding machine, the following method for efficiency of the fufu pounding machine was examined as follows: Tests were carried out on the constructed machine using $60 \mathrm{~kg}$ of boiled cassava for three different batches The time taken for each batch was accurately checked and recorded as shown in Table 3. Each tuber of cassava was weighed and the weight of the whole batch of cassava obtained. The following measuring parameters were obtained and compared with the results of tests on the constructed machine.

Table 3: Number of Loading and Time Taken For Each Loading to Evaluate Performance of the Machine.

\begin{tabular}{lll}
\hline $\begin{array}{l}\text { Number of Load- } \\
\text { ing }\end{array}$ & $\begin{array}{l}\text { Mass of Cassava } \\
{[\mathrm{kg}]}\end{array}$ & $\begin{array}{l}\text { Time Taken to Pound } \\
{[\mathrm{min}]}\end{array}$ \\
\hline First Loading & 2.00 & \\
& 2.55 & \\
& 2.58 & \\
& 2.75 & \\
& 2.78 & \\
& 1.98 & \\
& 1.88 & \\
& 2.05 & \\
& 1.50 & \\
Total & 20.07 &
\end{tabular}

Rate of Cassava Pounding $\left(\eta_{\mathrm{r}}\right)$

This is quotient of the weight $(\mathrm{kg})$ of cassava pounded per hour.

$$
\begin{aligned}
\eta_{\mathrm{r}} & =\frac{\text { weight of cassava pounded }(\mathrm{kg})}{\text { Time time taken }(\mathrm{hr})} \\
& =\frac{[20.07+21.08+18.85] \times 3600(\mathrm{~kg})}{[602+632+566](\mathrm{hr})}=\frac{216000}{1800}=120 \mathrm{~kg} / \mathrm{hr}
\end{aligned}
$$

Hence, the output of $120 \mathrm{~kg}$ of pounded cassava per hour indicates that the machine is of high productivity, efficiency and also saves time.

Considering the traditional way of fufu pounding, time and the manpower required in carrying out the operation, if it takes a minimum of $1-2$ hours to pound about $20 \mathrm{~kg}$ of cassava manually coupled with its unhygienic mode of operation, it will take about 10minutes to pound the same quantity of cassava with good output quality.

\section{Conclusion}

The home use/small scale cassava fufu pounding machine was developed and tested. It was found to be effective and efficient and could pound about $120 \mathrm{~kg} / \mathrm{hr}$. Finally, it is expected that with the low cost of manufacturing this machine, every restaurant, chop bar and homes should procure this machine to enable them prepare a good and hygienic fufu that will be devoid of filth, sweat and saliva in the traditional method of pounding fufu with pestle and mortar. Based on the construction materials selection and quality of fabrication work, the machine is durable and expected to last for about 10years.

\section{Acknowledgements}

The authors are grateful to Mr. Sule Seidu a Technician at GRATIS Foundation-Brong Ahafo Regional for his necessary support in the fabrication of this machine. We also acknowledge the Government of Ghana for providing the financial support for this research through the Book and Research Allowance.

\section{References}

[1] J. Chiamba, African cooking and Recipes, www.africancooking.org, Posted Mar 19, 2010, 2:34 AM, accessed on the 5th of June 2015

[2] http://sankofafufu.com/.

[3] C. O. Osueke, Design and Construction of a Yam Pounding Machine, Available online (blogsite), 2010 accessed on the 5th of June 2015.

[4] Volunteer in Ghana with G-lish foundation, http://www.glish.org/travel/fufu-relationship-wisdom, accessed on the 5 th of June 2015.

[5] E. Prestlokken and O. M Harstad, Effect of expander-treating a barley-based concentrate on ruminal fermentation, bacterial $\mathrm{N}$ synthesis, escape of dietary $\mathrm{N}$, and performance of dairy cows. Anim. Feed Sci. Technol., $90 \quad$ (2001), 227-246 http://dx.doi.org/10.1016/S0377-8401(01)00207-3.

[6] Budynas and Nisbett, Shigley's Mechanical Engineering Design, 8th edition, McGraw-Hill companies, 2008; 15-351.

[7] S. Kalpakjian and S. Schmid, Manufacturing Engineering and Technology, Pearson Education Inc., Upper Saddle River, New Jersey2006; 1246-1250

[8] R. S. Khurmi and J. K. Gupta, Shaft, V-belt and Rope Drives: A Textbook of Machine Design, 14th edition, Eurasia Publication House (PVT) Ltd., New Delhi, 2005; 456-498, 657-659.

[9] N.D. Frame. The Technology of Extrusion Cooking. New York, Blackie Academic and Professional, 1994 http://dx.doi.org/10.1007/978-1-4615-2135-8.

[10] H. S. Hall,A. R. Hollowenkand H. G. Laughlin, Theory and Problems of Machine Design, Schaum's Outline Series, 1980. 